Soft power and the challenges of private actors: Turkey - Kurdish Regional Government (KRG) relations and the rising role of businessmen in Turkish Foreign Policy

Merve Özdemirkıran

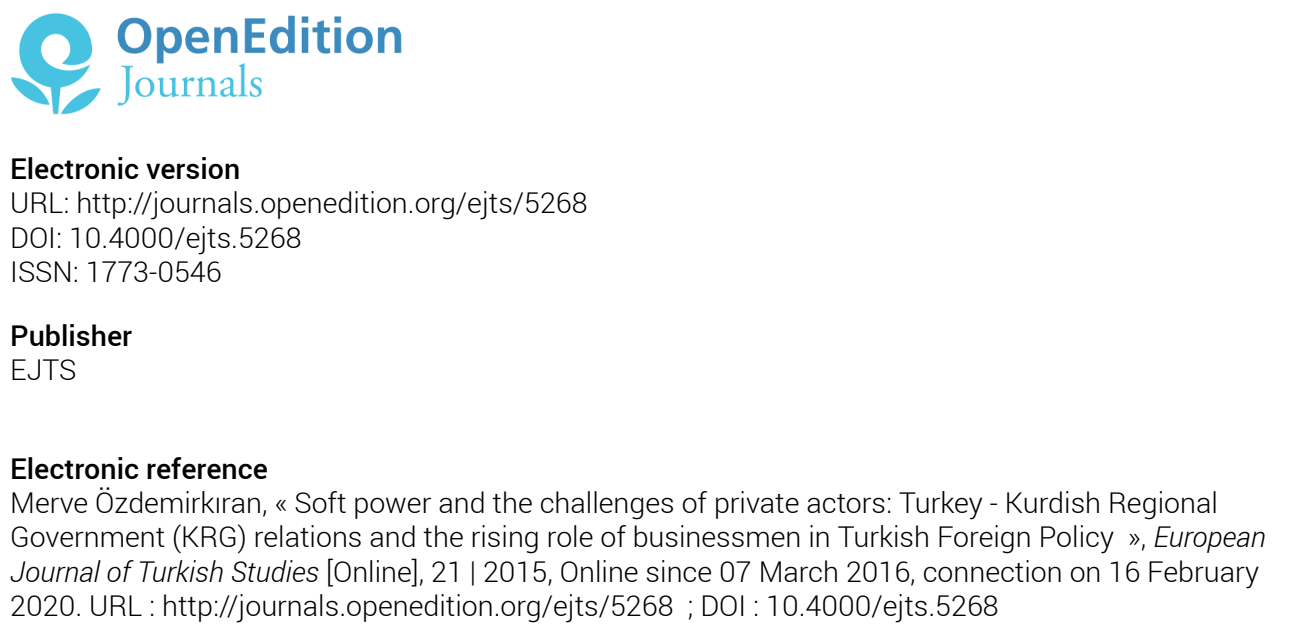

This text was automatically generated on 16 February 2020.

(c) Some rights reserved / Creative Commons license 


\title{
Soft power and the challenges of private actors: Turkey - Kurdish Regional Government (KRG) relations and the rising role of businessmen in Turkish Foreign Policy
}

\author{
Merve Özdemirkıran
}

Although the formation of a Kurdish state in the Middle East is a political taboo in Turkish foreign policy, Turkey adopted a more pragmatic position when Iraqi Kurds started to build a Kurdish state in 2005, when the new Iraqi constitution was proclaimed. The constitution did not only give the Kurds political autonomy but also economic independence since they control $17 \%$ of Iraqi oil resources. Currently, businessmen from Turkey, both Turks and Kurds, are contributing to the construction of this quasi state's ${ }^{1}$ physical infrastructure, while the majority of food and other products are exported from Turkey. Indeed, Iraq quickly became Turkey's fourth largest economic partner: Turkish-Iraqi trade is worth over $\$ 7$ billion and, according to the Turkish consulate's statistics in Erbil, $65 \%$ of this is with the Kurdish Regional Government (KRG) specifically. ${ }^{2}$ These businessmen are building bridges, highways, airports, universities in Iraqi Kurdistan, while Turkish is gradually becoming the dominant language of the shop signs and business in general. Through such activities, businessmen from Turkey have established a bridge between Turkey and the KRG, which has generated the conditions for developing bilateral political relations. Considering the violence provoked in the whole region by the Syrian civil war since 2011, Ankara's relations with its eastern neighbours are dramatically affected. Yet, Erbil is today the only capital with whom Ankara has maintained its good relations and 
developed alliances in order to cooperate particularly for border security issues in the framework of the fight against ISIS.

The role these businessmen play in Turkey's involvement in KRG state building illustrates economic interdependence in Turkey's foreign policy and shows how the state uses economic activity in order to attain its foreign policy objectives. In fact, one of these objectives is to expand Turkish influence by using soft power, which is currently being prioritised in Turkish foreign policy, especially towards the Middle East. Turkish soft power is basically defined by "the values that Turkey represents, by its history, culture, its capacity to mobilise regional dynamics and to create new spheres of influence" (Kalın 2012). Turkey's economic capacities play a central role in creating these new spheres. Turkey's business activities in KRG can thus provide reliable empirical data to further analyse Turkey's regional policy towards its "new" neighbour, with whom security conflicts are not yet resolved. In other words, Turkey's position towards the Kurdish state building is a relevant case of the use of the soft power as a foreign policy tool.

Soft power (or co-optive power), first defined by J. Nye, is usually considered as a tool controlled by public actors. States usually possess a variety of hard and soft power tools that they can outsource to societal agents (Vuving 2009). In the case of Turkey's soft power in KRG, however, private actors - businessmen - play the major role. Their activities have prepared the basis for bilateral relations and created a favourable context for Turkey to influence KRG. The Turkish state has taken advantage of these activities in order to achieve its foreign policy goals, including spreading its soft power in the Kurdish region. Thus, the positive situation has been created by private actors, who actually avoid state control because of the effect of Turkey's Kurdish question, while the benefits are felt by the state.

The consequences of these activities and the relations of these businessmen with the state make the concept of soft power more complex as an analytical tool. These activities do not only influence foreign policy but also affect Turkish domestic politics. Turkey's Kurds with business activities in KRG are challenging the state in order to enlarge their negotiation space as members of a minority. Thus, Turkey's minority issue becomes linked to a soft power foreign policy issue. This leads to the question of how much soft power remains an explanatory context when analysing relations between private actors and the state. This phenomenon therefore needs to be explained within the general context of Turkey's use of soft power in its international relations. This article aims to show, through the case of Turkey's businessmen in KRG, how the concept of soft power gains a larger definition as a means for private actors. These actors benefit from the state's desire to expand its soft power, in order to strengthen their influence in domestic politics.

The empirical data for this study comes from 45 semi-structured interviews conducted in Turkey (Istanbul, Ankara, Gaziantep, Diyarbakır) and in Northern Iraq (Erbil) between 2008 and 2011 with businessmen and representatives of business associations and chambers of commerce and industry in these cities. ${ }^{3}$ This article focuses on interviews with those businessmen who are also representatives in chambers of commerce and industry bodies. Their position in these organisations provides relevant empirical data to analyse the access of private actors to the political sphere and relations between the state and these businessmen, specifically Kurdish businessmen from southeast Turkey. The interviews show that businessmen from Turkey conducting 
economic activities in KRG can be divided into two principal groups through their ethnic identity: Turks or Kurds. Their motivations, size of their activities, relations with state authorities in Turkey and KRG, manner of access to the KRG market depend primarily on this ethnic factor.

When the activities and positions of these business actors are analysed within the framework of Turkish soft power, three main stages can be identified. First, their activities were not officially supported by the Turkish state until the opening of the Turkish consulate in Erbil. That is, from 2005 to 2010, businessmen contributed to Turkey's soft power in spite of the state. Kurdish businessmen from southeast Turkey have played a key role through their kinship and language skills. Their motivation to contribute the emerging Kurdish quasi state has enabled the development of economic exchange between Turkey and KRG. In contrast, during this period, few Turkish businessmen were committed to these economic relations while they experienced many obstacles, such as long delays at the Turkish Iraqi border. More recently, these business people have been integrated with the Turkish state's policy of economic integration with Northern Iraq. By opening a consulate in the Iraqi Kurdistan's capital, Erbil, the Turkish government recognised symbolically the autonomous status of KRG, which made Turkey's soft power strategies more visible in the region. The third stage relates to the new status that businessmen, especially Kurds from southeast Turkey, gained by being in harmony with the state's new foreign policy objectives. This agreement has allowed them to participate in foreign policy decision-making processes, where they can negotiate their conditions with the state and ultimately achieve more influence in domestic politics.

In the following sections, these three stages will be analysed within the general framework of relations between the state and businessmen in Turkish foreign policy. The political impact of business activities on soft power will be emphasised to show how non-state actors are using their status in the state's soft power strategies to strengthen their negotiation capacities with the state.

\section{The influence capacities of businessmen regarding Turkish foreign policy}

Over the last thirty years, the actions of businessmen have had a considerable impact on decision-making in Turkish foreign policy due to the intensification of economic exchanges on a global scale, the consolidation of financial markets and the development of communicative tools, as a result of economic globalisation. Although the multiplicity of means of action, organisational models and institutional or social structures of the variety of stakeholders that have emerged at the centre of globalisation regularly affect international relations, it is the economy and economic stakeholders that critically determine foreign policies (Carron de la Carrière 2002: 270). That is, economic factors, unlike others, are always present, even omnipresent (Carron de la Carrière 2002: 271).

The omnipresence of the economy also leads actors to avoid armed conflict in order to preserve their economic interests in the international system. States, developed countries in particular, avoid conflicts between themselves and regularly seek means of cooperation to resolve disputes non-militarily, without wasting their large military budgets (Doyle 1997). Thus, the international system, controlled by economic factors, 
no longer supports direct armed conflict between developed states. By abandoning armed methods and further concentrating on economic factors and means, these states have created a trading world, albeit one that remains imperfect or even powerless to prevent conflicts at times, and criticised by the originator of the concept, R. Rosecrance. $^{4}$

In the context of economic globalisation, businessmen and their organisations are considered more and more frequently as central stakeholders in the international system. Furthermore, as the liberal approach to international relations theories states, international economic exchanges that contribute to the growth of the actions of businessmen constitute a solid basis for maintaining international peace, a critical phenomenon that helps states avoid potential conflicts. International economic exchanges, maintained and developed by economic stakeholders, allow states to consolidate reciprocity and interdependence.

Economic stakeholders can also be characterised as transnational actors in their internationally created networks, their organisations at national and international levels, in their capacity to influence international bodies and establish, in certain circumstances, a rival to the state. Their transnational character, which is to say their capacity to act beyond all borders (physical, legal, social, psychological, etc.), permits them to develop a strong capacity to orient or determine state foreign policy strategies while creating a parallel space to international relations, a space dominated by transnational relations (Nye and Keohane 1972). Transnational relations include all relations that, whether by deliberate will or by destination, take place in a global space beyond a state's national framework which produces itself by at least partially escaping the control or the mediating actions of states (Badie and Smouts 1995: 70).

Among these transnational stakeholders, businessmen and their organisations are characterised by their relatively privileged position and specific relations with states. In the current global economic system, their actions, the results of their activities and, at times, their opposition to state policies affect these policies more directly than other transnational stakeholders. Furthermore, this influence enables them to gain state recognition as "legitimate stakeholders" that can participate in the decision-making process. In this way, they manage to impose themselves more effectively in the political sphere (Winters 1996).

The era of globalisation and, most importantly, the progressive integration of the Turkish economy with international markets following the transformation of Turkey's national economy to a free market in the 1980s, gave Turkish businessmen a new source of legitimacy. They enlarged their negotiation space with the state which -as many studies on the state/business-world relationships (e.g. A. Buğra 2007; M. Heper 1991) and on the history of the political economy in Turkey, (e.g. ç. Keyder 1987; K. Boratav 2012) state- controls economic policies, determines the country's economic objectives, and manifests itself as the principal economic stakeholder and which also therefore defines the scope of entrepreneurs and their interest groups.

Indeed, the Turkish state, at least until the 1990s, imposed control, predominantly in the economic sphere, to limit the emergence of new "fields of power" (champs $d u$ pouvoir) that, according to P. Bourdieu, are formed by the holders of other kinds of capital, be it cultural, symbolic or economic. These fields of power construct themselves as a game-space, at the centre of which the holders of different kinds of capital struggle, particularly for power over the state. By exerting power over state 
capital they gain power over other kinds of capital and their reproduction (Bourdieu 1993: 52). Fearful of all types of rivalry from capital-holders (for example intellectuals, artists and above all entrepreneurs) who can endanger its monopoly over the control of resources, the Turkish state limited the autonomy and the space of action of (private) holders of economic capital, the businessmen. Therefore, these economic stakeholders held back so the Turkish authorities could not use the economy as an effective foreign policy tool.

Since the beginning of the 1990s, despite previous difficulties, the Turkish economy has developed steadily, with foreign trade occupying a prominent place. It has grown 15 times larger in the last twenty-five years while being profoundly modified, and now constitutes the fulcrum of the Turkish economy. Whereas Turkey used to export agricultural and mining products in the early 1980 s (57\% of exports came from agricultural products, for example), nowadays $90 \%$ of Turkish economic exports come from industrial products (textiles and clothing, intermediary goods, and consumer goods such as cars and household appliances) (Insel 2008: 131). This economic expansion has made foreign trade an increasingly valuable foreign policy tool, while making Turkey a trading state, a state able to use international economic exchange as an integral element for determining its foreign policy (Rosecrance 1986).

Turkey's foreign policy and Turkey's integration into the international system, for example its European Union candidacy, have become a new space for Turkish businessmen to influence. Through their economic activities abroad, they have started a new relationship with the state and gained greater "legitimacy" in negotiations with the state while playing an intermediary role between Turkey and foreign countries. According to Buğra, if Turkish entrepreneurial activities fully agree with the state's self-defined interests and objectives then this compatibility makes the state consider their activities as legitimate ${ }^{5}$ (Buğra 2007: 42).

The new critical role of economic stakeholders in the international system with the development of transnational relations supports Turkish businessmen, especially since successive Justice and Development Party [Adalet ve Kalkınma Partisi - AKP] governments have set a foreign policy goal of making Turkey a regional power, even a global player, due to its economic growth. The domestic transformation of Turkey's political economy has brought the political and economic spheres closer together, as M. Kutlay argues: "the restructuring of domestic business actors and the emergence of a new competitive capitalist class underpinned the economic arm of Turkish foreign policy". Thus, the economy became "the practical hand" of Turkey's new foreign policy (Kutlay 2011).

Since the beginning of the 1990s, new conditions governing foreign policy have given Turkish businessmen and their associations a unique opportunity to participate more actively in policy-making. ${ }^{6}$ Even if their activities correspond to the state's goals and interests, that is, to those national interests that have been the principal source of legitimacy for entrepreneurs since the Turkish republic was founded, the role of international economic exchanges in Turkey's relations with foreign countries is giving them for the first time an autonomy that allows them to strengthen their position in domestic affairs. Moreover, as noted by K. Kirișçi, the nature of the trading state requires the involvement of many stakeholders in the formation of foreign policy or diplomatic games. However, the priorities and interests of these stakeholders 
sometimes differ from those of traditional foreign policy makers in Turkey (Kirişçi 2009).

Through their "legitimacy" and state recognition when their actions coincide with the broad lines of foreign policy, they become stronger stakeholders in domestic policymaking. Thus, foreign policy, which is, with a few exceptions (e.g. Z. Öniș), underresearched in the existing literature on state/businessmen relations in Turkey, becomes a key variable for analysing relations between the Turkish state and businessmen. Turkey's EU candidacy is a prime example of how businessmen have become influential stakeholders in politics in that the outcome of the Helsinki Summit led the political and economic key players in Turkey to take the initiative in implementing EU-mandated institutional changes (Öniş and Bakır 2005).

During this particular period, and also later, businessmen and business associations were charged with overseeing legislation and implementing reforms demanded for EU integration, thereby acting as central players in Turkish civil society. Furthermore, they intervened in the debate on Turkish democratisation by influencing domestic policy. Indeed, the way Turkish entrepreneurs, large corporations and large groups from Istanbul's republican bourgeoisie, viewed Turkey's EU accession efforts is particularly interesting. In one study analysing the attitudes of Turkish citizens regarding the economic, political, and cultural effects of Turkey's EU candidature, businessmen were notable for their support for Turkey's EU accession while exerting a certain pressure at a national level to drive the political authorities to pursue reform. Macroeconomic stability, the EU's development support, foreign direct investments (FDI), expanding the market for Turkish exports through preferential trade agreements with EU member states all motivated businessmen to push Turkey's political leaders to move forward towards achieving EU membership (Aybar et al. 2007: 337 and 347).

This involvement of businessmen in the European project throughout the 1990s and at the beginning of the 2000s, made this group a key stakeholder in civil society. As an intermediary player between Turkey and foreign states, these businessmen were recognised by the state as an actor in foreign policy. According to Z. Öniș, through their support for Turkey's candidacy and EU accession, business associations, particularly TÜSİAD [Türkiye Sanayici ve İșadamları Derneği - the Association of Turkish Businessmen and Industrials], remained integral drivers of this project domestically due to their influence on the state and political actors (Öniş 2006: 284-292).

As well as willingly supporting the work of businessmen and associations like TÜsİAD in the European project, particularly between 1999 and 2002, the AKP government also favoured their business activities in targeted regions (the Middle East, Africa, Central Asia) as part of A. Davutoğlu's foreign policy strategy. AKP has a close relationship with the "pious" business community of Anatolia that has for over ten years constituted the "new bourgeoisie" in Turkey. MÜSİAD, ${ }^{7}$ which is made up of representatives of this new pious bourgeoisie, has been progressively taking the place of TÜSIAD, which is now considered as representing "Istanbul's former, secular and Western bourgeois class". ${ }^{8}$ This newly emerging bourgeoisie currently accomplishes the tasks assigned to Turkish businessmen within the framework of the diplomatic goals of Turkey's political leaders: the establishment of an "economic diplomacy", which has also been applied by other emerging economies, such as China, South Africa, Brazil and India. The goals of economic diplomacy allow businessmen to acquire a unique legitimacy (albeit similar 
to that of TÜsİAD within the European project) due to the perfect compatibility of their activities with the national interests determined by political leaders. ${ }^{9}$

Economic diplomacy involves using a country's tools and capabilities (trade, investment, finance, organisation, development, etc.) to protect its interests in its relations with both neighbouring countries and countries outside its region, and also in decision-making bodies of the international system, while operating from a logic of cooperation without resorting to force or direct coercion. Economic diplomacy requires the state to develop its soft power in foreign relations, which enables it to become a key player in international negotiations.

\section{The role of businessmen in Turkey's relations with the KRG}

A policy that implements economic diplomacy considers businessmen as central stakeholders in the process. Businessmen conducting economic activities within the territory of a de facto Kurdish state have thus become the bearers of an economic tool in Turkey's policy, which has enabled them to acquire a certain level of compatibility with the national interests determined by the government. Consequently, despite predictable conflicts between Turkey and the KRG regarding border security and the presence of PKK militants on Kurdish soil, and despite the opposition of Turkey's military (at least until 2010), Turkey's political authorities have not restricted the businessmen's activities. Furthermore, they have not openly challenged the legitimacy of these activities, which are also essential for any entrepreneurial economic activity in Turkey to survive and succeed (Buğra 2007). In other words, the Turkish businessmen's activities in the Kurdish region of Iraq have gradually inscribed themselves in Turkey's foreign policy as a trading state.

Until the opening of the Turkish consulate in Erbil on March 11, 2010, the Turkish state had not established a specific policy regarding this new category of stakeholders who were certainly supporting economic relations with the KRG according to most state leaders. ${ }^{10}$ However, their activities were not yet recognised as a key element in political relations as Turkish public opinion was still quite sensitive regarding the Kurdish question and the presence of rear PKK bases on KRG soil. As one entrepreneur, who had experienced business problems due to a lack of Turkish diplomatic representation in KRG, states, "the government was neither a support nor a hindrance" during this period. ${ }^{11}$

\section{Conditions in which entrepreneurs started their business activities}

Trade between Turkey and KRG is relatively specific with respect to business conducted by Turkish entrepreneurs in other countries. Border security issues related to the Kurdish conflict and the unsatisfactory development of the Kurdish question in Turkey have both hindered the economic relationship while paradoxically strengthening the role of businessmen.

As mentioned in the introduction, the group of businessmen analysed in this research is not homogenous but forms two groups: owners of big businesses and owners of small and medium size enterprises, considering the type, volume and size of their economic 
activities. Regarding sociological characteristics, the principal point of division corresponds more or less to an ethnic division between Turks or Kurds.

At the same time, however, there are many intersections between these two main groups. The majority of big business owners are Turks with businesses mainly sited in western Turkey whereas owners of small and medium business are mostly Kurds from southeast Turkey where the Kurdish population is the majority. When these businessmen were asked to explain their initial motivation to conduct business activities in KRG, regardless of business size and location, Kurds replied that ethnic identity was the source. They stated that they started business activities in KRG for "observing the first steps of the first Kurdish state, contributing to the economic development of this quasi state and also developing Turkey's southeast economic structure." These motivations are thus not necessarily linked to traditional business interest motivations. ${ }^{12}$ Turks' motivations were significantly different. The most salient was to find new business markets and partners in the Middle East to avoid the negative effects of the 2008 global economic crisis. Some of them also stated that their activities "contribute to Turkey's regional power capacities in the region and they support a peaceful dialogue between Turkey and Iraqi Kurds" (Özdemirkıran 2013).

The businessmen, both Turks and Kurds, persisted with their activities despite the reluctance of Turkey's state authorities, a lack of support or state incentive, and restrictions, security threats and tensions between Ankara, Erbil and Bagdad because of PKK bases in Qandil, long queues at the Khabour border gate because of these tensions, and hostile public opinion in Turkey.

One of the most important common problems that affected business conditions was blockages at the Khabour border gate. These long queues had three causes. First, numerous local merchants from the border region are conducting cross-border trade activities in mini-vans (buying cigarettes, tea, rice, etc. from Iraq to sell in Turkey at a higher price). Because their status is not clearly defined, the merchants and their merchandise have to pass regular controls without using commercial procedures reserved for recognised trade activities. This unclear status creates chaos at the border where only 4 or 5 out of 30 counters are usually open. Even though businessmen from southeast Turkey welcome these activities for local economic development, they also demand structural changes at the border and a privileged procedure for crossing the border to bypass the local merchants' queue, to enter KRG more quickly to sign contracts, contact their partners or develop their business. The second problem is that, until the end of 2010, there was a second checkpoint at Khabour operated by the military, at which Turkish citizens were asked to declare their reason for entering Kurdistan. This caused long waits and sometimes even refusals for businessmen from Turkey. Third, tension between KRG and Turkey rose because of Turkey's military raids into the Qandil mountains against PKK militants and politicians' hostile declarations. ${ }^{13}$ Nevertheless, businessmen have continued their activities despite these unfavourable conditions. In other words, they have carried out activities that benefit the Turkish state, despite its conscious and unconscious restrictions, by developing economic relations and laying strong foundations for further cooperation between Turkey and KRG.

My field study in Turkey and Northern Iraq on businessmen's economic activities in the KRG shows that businessmen are indeed at the origin of the improved political relations between Turkey and KRG. While the implementation of a trading state 
strategy and the willingness of the state to diffuse its soft power economically were certainly central to their business activities, at least up until 2010, it was businessmen themselves who were the central stakeholders in bilateral relations. In fact, they are the ones who convinced the Turkish state to open a diplomatic representative body in the Kurdish capital, Erbil. The opening of the Turkish Consulate in Erbil is indeed a great success story for Turkish businessmen, which demonstrates their influence over the state.

\section{Diplomacy follows economy}

Turkish diplomacy has come to Kurdistan through the pressure of businessmen whose demands and organisation have affected the decisions of the Turkish authorities. It should be noted here that opening a diplomatic representation in Erbil amounts to a symbolic recognition of Kurdistan, which was previously taboo in Turkish politics. Although Turkey had recognised KRG's autonomous status by recognising the Iraqi Constitution of 2005, the implementation of this recognition, and the transition from an informal to formal situation, took time for the Turkish authorities and Turkish public opinion.

The Gaziantep and Diyarbakır Chambers of Commerce mediated between the Turkish state and Turkish businessmen. The economic representatives of the two southeastern Turkish cities that benefit the most from economic exchanges with KRG actively engaged themselves in communicating entrepreneurial requests to the state and expanding trade with Iraq. For example, Mehmet Arslan, former president of Gaziantep Chamber of Commerce, several times invited former secretary of state in foreign trade, Kürşat Tüzmen, to Gaziantep, especially for the exposition Gateway to Iraq ${ }^{14}$ in order to bring together the minister and businessmen active in Iraq or who were planning activities there. ${ }^{15}$ Gaziantep Chamber of Commerce also prepares regular export reports for the Ministry of Economy in which it emphasises the needs and priorities of its members. Personal political relations of the president and other influential members also allows the problems, needs and propositions of local businessmen to be communicated to Ankara. Diyarbakır Chamber of Commerce and Industry is also very much committed to developing relations between state authorities and local business actors. For example, its former president, Mehmet Kaya, organised a meeting in 2008 in Diyarbakır with representatives of Erbil Chamber of Commerce and local political authorities, including the Governor, and Deputy Governors from various parts of southeast Turkey. This meeting, which took place at a very crucial moment when the political tension in the region was high just after PKK attacks on a police station in Aktütün, gave birth to a commercial protocol between Diyarbakır and Erbil Chambers of Commerce. This protocol became a model for other chambers that signed commercial agreements with Erbil Chamber of Commerce ${ }^{16}$.

Galip Ensarioğlu, another former president of Diyarbakır Chamber of Commerce and Industry agreed that "the Chamber was fighting for a consulate in Erbil", adding that during each meeting with the political authorities in Ankara he stressed the necessity of this consulate to enable the activities of Diyarbakır's businessmen to continue. He used his personal political relations to express the needs and problems of local entrepreneurs regarding economic activities in KRG. ${ }^{17}$ 
The establishment of the Association of Turkish-Iraqi Businessmen and Businesswomen [Türk-Irak Ortadoğu İşkadınları ve İşadamları Derneği] in 2009 also allowed businessmen to increase their relations with Turkish and Kurdish leaders to negotiate, without intermediaries, about their specific requests concerning Turkish-Iraqi trade. The president of this organisation, Sıdıka Halıcıoğlu, and her vice-president, Erkut Temiz, conceived what they called "the summit of the Turkish economy", in which the president of TOBB, Rifat Hisarcıklıŏlu, and Zafer Çağlayan, former Minister of Economy, obtained direct meetings with the aim of explaining the general problems affecting economic activities between Turkey and Iraq and the requests of all businessmen, not only the requests of members of the association. ${ }^{18}$

With the explicit consent of the Turkish state through the opening of the consulate, business activities multiplied in Kurdistan. As Soran Aziz, vice-president of Erbil's Chamber of Commerce, put it, "businessmen began to 'run' towards Erbil". ${ }^{19}$ The consulate has facilitated business travel from cities in western Turkey to Iraq. Business people from Turkey had previously been reluctant to seize the economic opportunities offered in the Kurdish region of Iraq due to general prejudices in Turkey about "Kurds". For example, the secretary general of the Chamber of Industry in Istanbul, who was interviewed immediately following a visit to Erbil with a group of members of the chamber, stated that official diplomatic representation in Erbil eased his members' safety concerns and convinced the board of directors of the Chamber of Industry of Turkey's largest city to organise a discovery trip:

Indeed, after the crisis [of 2008], Iraq was on the agenda as a potential market among the countries of the region, but we didn't dare to take a step towards Iraq, for security reasons. Now, when our official representatives called upon us for a possible visit while ensuring security conditions, we decided to go and the political decision of the Turkish state to open a consulate reinforced our decision. ${ }^{20}$

As part of the new trading state policy in the region, and particularly concerning KRG, businessmen played a principal role in developing Kurdish-Turkish relations: "They were equally diplomats, intermediaries, and a source of information for the Turkish government." ${ }^{21}$ Their activities created an interdependent relationship between Turkey and KRG while also convincing politicians to abandon the logic of conflict to bring the political language in line with the economic. In this, they took on the role of a diplomat, who, according to R. Aron, "should lead the diplomatic-strategic conduct and speak on behalf of the collective of the state, accompanied by the 'soldier' who kills in the name of the aforementioned collective of the state" (Aron, 2008: 17).

These businessmen currently place a distance between the soldier and the diplomat, and accompany and guide them despite their non-state character. The traditional cooperation between the diplomat and the soldier, the two representatives of the state, have transformed themselves to the benefit of the businessman involved in foreign policy. The case of Turkish businessmen economically active in Kurdistan is a clear example to emphasise the change from a policy determined from a perspective of probable conflict to a policy determined by potential cooperation, especially economic, favoured by the new ruling elite in Turkey, whose political rise is closely linked to Turkey's economic development.

These economic exchanges have facilitated the development of government policies and official links with KRG. The first official high-level visit to KRG was organised with businessmen accompanied by the then Minister of Foreign Affairs, A. Davutoğlu, and the former Minister of the Economy, Zafer Çağlayan (at the time, the Under-Secretary 
for Foreign Trade ${ }^{22}$ ). According to Sidıka Halıcioğlu, President of the Association of Turkish-Iraqi Businessmen and Businesswomen, who was among the entrepreneurs that accompanied the two ministers on this visit, the Turkish state called on businessmen to organise this first official visit. Halıcıoglu was called by the Minister of the Economy, who wanted to ensure that she participated in the delegation. However, she politely refused to travel with the ministers:

Since after all the efforts that I had made with Mr. Dara [Dara Ali, the President of the Chamber of Commerce in Erbil, a central figure in relations between Turkey and KRG] for the development of trade, I wanted to host the ministers as a hostess from Erbil to speak with them about this trade. ${ }^{23}$

The president's position confirms the distance that entrepreneurs want to keep between themselves and the political sphere in order to stand together with their Iraqi counterparts when a visit with state stakeholders takes place. It also reinforces the relative independence that Turkish entrepreneurs are beginning to have in their relations with the Turkish state, demonstrating that they prefer to preserve their nonstate character.

During this visit with the businessmen, A. Davutoğlu officially announced Turkey's decision to open a consulate in Erbil, adding that the diplomatic delegation's members were all to feel at home and that the common will would rebuild the Middle East with feelings of closeness. He also focused on the economic development of Erbil: "We can jointly contribute to the development of Erbil. This will be a bridge between Turkey and Iraq. We [Turkey] are the open door between Iraq and the European Union and Erbil is our open door to Basra" (Zaman Oct. 31, 2009). This visit aroused great enthusiasm in KRG, with headlines like "Turkey has recognised Iraqi Kurdistan" and "Let's all do business in the Middle East!" (Çubukçu Nov. 3, 2009).

Soran Aziz, Vice President of the Erbil Chamber of Commerce, said with joy shortly before Turkish Prime Minister Erdoğan's visit to Erbil in March 2011: "the economy that brought the Prime Minister to Erbil". ${ }^{24}$ The two main topics of the meeting between Erdoğan and Barzani concerned the economy and security.

\section{Beyond soft power. From state strategy to non- state actors' benefits}

\section{Turkish soft power consolidated by the economy}

The economic activities discussed here have contributed to Turkey's soft power. Soft power is the primary tool of a trading state, which, rather than prioritising its military capabilities above all other advantages, imposes its will through economic strength, language or cultural influence.

The economic activities of businessmen from Turkey have led Iraqi Kurds to learn Turkish, for example. Learning Turkish is becoming increasingly lucrative for the Iraqi Kurdish youth, who consider Turkey as their only opening to the West and international markets. ${ }^{25}$ Accordingly, Kurdish businessmen and shopkeepers in Erbil, Souleimaniya, Dohuk and Zakho increasingly speak Turkish. Similarly, it is not uncommon nowadays to meet a Kurd who speaks Turkish on the city streets, mentioning Turkish film and television stars, or young Turkish-speaking Kurdish businessmen coming to the consulate in Erbil with their Turkish associates to sign 
contracts or apply for visas to meet other businessmen in Turkey. As the Commercial attaché of the Turkish consulate in Erbil, D. Kutlu mentioned, visa applications have increased at a "dizzying rate". ${ }^{26}$

KRG's economic dependence on Turkey gives rise to a cultural closeness with Turkey, which wishes to influence the region both culturally and politically, using the instruments of soft power. Turkish private schools, known as "Gülen schools", have been recently added to Turkey's presence. Economic exchanges prepare the groundwork for such influence, even in a region whose existence and even name, "Kurdistan", were long considered taboo and previously expressed with contempt by both Turkish leaders and the Turkish public. Turkey now conducts relations with KRG while trying to avoid conflicts due to the Kurdish question in the region by applying the same strategy developed for all dealings with the Middle East, which avoid direct military intervention while focusing on soft power. As claimed by Meliha Benli Altunıș1k, despite the limitations imposed by the political and economic structure of the region, Turkey has every chance to pursue a policy of soft power in the Middle East since, as compared to its neighbours in the region, it has implemented social, economic and political structural reforms that make it stronger and influential internationally (Altunışık 2005).

Nearly all the businessmen interviewed noted that economic exchanges have led the Iraqi Kurds to deepen their relations with Turkey, buy real estate in major Turkish cities to spend their holidays and, most importantly, send their children to Turkey for higher education. Muhammad, for example, the son of a businessman from Erbil, who studied law at Bilkent University in Ankara, said that going to study in Turkey is as prestigious as going to the United States or Europe:

All my friends and me, we went to the Turkish school, Ișik Koleji, it's one of the best schools here. Now, thanks to my Turkish, I help my father in his businesses with the Turks. ${ }^{27}$

The case of relations between Turkey and KRG shows how the mobilisation of economic resources can play a central role in solving political problems caused by previous conflicts. Turkey is consolidating its presence in Kurdistan through its products and culture (language, popular culture), using its soft power as the main tool to aid its goal of becoming a regional power. As for KRG, Kurdish leaders seek to develop their relationship with their Western neighbour, a candidate for the European Union, the $17^{\text {th }}$ global economy, a member of NATO and the G20, in short their only neighbour which is integrated with the Western world and that takes part in the international system. Even if the Kurdish government preferred that the Kurdish region remain within the federal system in Iraq, every Iraqi national crisis that creates obstacles to the KRG's state building process leads the Kurds to make statements suggesting their possible independence. These statements indicate that independence is the ultimate goal of the Iraqi Kurds, although it has been put on hold by KRG leaders during Iraq's reconstruction process since 2003. Federal problems have led Iraq's Kurds to develop independent policies, to seek ways to self-manage their economy (especially regarding oil resources), to establish strong ties with foreign countries through the investment opportunities they offer, and to build an independent foreign policy through these economic relationships. For example, in May 2012, KRG announced a proposed pipeline to transport one million barrels of oil per day to Turkey, which the Turkish Minister of Energy welcomed. However, the central government in Baghdad severely criticised this 
proposal, denouncing the attitude of the KRG, claiming to be the sole legitimate holder of power concerning Iraq's natural resources (Çandar May 26, 2012).

This announcement was made after KRG Prime Minister Nachirvan Barzani's visit to Ankara. Since the beginning of 2012, Ankara's relations with Baghdad have cooled. Indeed, Turkey, which had been slow to open a consulate in Erbil, is now beginning to take the Kurdish leaders more seriously and privilege its relations with them to ensure their energy needs. Turkey is beginning to consider the KRG as a future independent state rich in natural resources, a neighbour with whom bilateral relations, which can develop on an economic basis, need to be improved. In fact, Turkey's trading state foreign policy led by Turkish and Kurdish leaders has allowed them to build a political dialogue that has been gradually transformed into bilateral political relations. The Diyarbakır meeting of Masoud Barzani and Tayyip Erdoğan in November 2013 illustrates perfectly this emergence of a political partnership between Turkish and Kurdish governments. Moreover, despite many structural changes in the Middle East caused by the violence around the Syrian civil war, this partnership persists. Ankara and Erbil, both maintained economic and political ties in order to develop an alliance especially in the domains of energy and security. Border security issues linked to the ISIS threats, involvement of both capitals in the fight against ISIS, Turkey's military commitment in Bashika base in Mosul, challenges and fight against PKK in the South East Turkey after the failure of the peace process $^{28}$ for the resolution of Kurdish question since summer 2015, all made this partnership even more crucial for both sides. In an interview where he has called on global leaders to broker a new deal in the Middle East paving the way for a Kurdish state, KRG president M. Barzani declared that Turkey would not oppose KRG's independence (Chulov Jan. 22, 2016). What makes this declaration more important is that it was pronounced in a very sensitive period where fights between Turkish security forces and PKK militants were intensive in several city centres in the South East Turkey. That shows Ankara-Erbil relations are going beyond Turkey's Kurdish question.

\section{Legitimisation of Kurdish entrepreneurs in Turkey}

The Kurdish question is an international and transnational issue with obvious direct consequences for economic activities between Turkey and KRG that are linked to the minority question at the national level in Turkey. The businessmen's contribution to the economic development of a Kurdish quasi state in the Middle East is a controversial subject in Turkey with public opinion being quite hostile ${ }^{29}$ to the formation of a Kurdish state when business activities started in 2005. The case of Turkey's Kurdish businessmen thus offers an interesting case to explore how a business group from a marginalised ethnic minority can obtain a new status when its activities are compatible with state-defined foreign policy goals, and how the economy, as a tool of soft power, can become a tool for this particular group to express their regional political demands for southeast Turkey.

Economic activities between Turkey and KRG fall within a context where economics and politics are superimposed. Moreover, they include foreign policy and domestic questions, such as the Kurdish minority issue in Turkey. As previously stated, my field work indicated that the main variable for categorising the businessmen interviewed is ethnicity. Their motivations, modes of access, relations with the political sphere, both in Turkey and KRG, their stakes and challenges, problems and support were basically 
determined by whether they were ethnic Kurds or Turks. In this sense, the economic commitments of a Kurdish businessman have many more political consequences than those of a Turkish businessman. Even if both groups have been criticised by certain state actors (e.g. the military), political parties (Turkish nationalist parties) and public opinion, especially up to $2009,{ }^{30}$ for assisting in KRG's state building process, which was perceived as a threat to Turkey's security, Kurdish businessmen, especially those based in the southeast are additionally considered as volunteers and main economic supporters of the Kurdish state formation in Iraq. Until 2010, when the army checkpoint at the Khabour border has stopped its control activities, some Kurdish business people suffered economic damage after they were refused access to the border. However, by opening its consulate in Erbil, the Turkish state confirmed its commitment to bilateral relations and economic activities, which at the beginning were not supported domestically, as tools of Ankara's foreign policy objectives.

Their compatibility with the state's foreign policy objectives and soft power strategies allowed Turkey's Kurdish businessmen to build up a new and special relationship with the political sphere. Soft power, which is traditionally defined, designed and controlled by the state, has become, in the case of Kurdish businessmen, an instrument for nonstate actors, giving them the opportunity to create a new and specific space at a national level. Thus their contribution, through an ethnic motivation initially, to the state building process of a neighbouring state, has had consequences for Turkey's domestic minority question while empowering these non-state actors in relation to Turkish state authority.

As the former president of the Diyarbakır Chamber of Commerce and Industry, Mehmet Kaya, noted, “businessmen's travels to Iraqi Kurdistan abolished taboos, and trade normalised Turkish-Kurdish relations. This normalisation will change public opinion towards Kurds in Turkey; it will be an opportunity to solve the Kurdish question in Turkey". He also underlined that the principal reason for his commitment was to contribute to the Southeast's economic development and obtain opportunities for the resolution of Turkey's Kurdish question. ${ }^{31}$ Ferda Cemiloğlu, a committed Kurdish-origin businesswoman in Turkey-KRG economic and political relations, shares the same will. She stated that she is not doing business in KRG out of economic interest, but for the Kurdish nation's economic development, which has strategic importance for both Iraqi and Turkey's Kurds. ${ }^{32}$

Ironically, these particular motivations of Kurdish businessmen are no longer perceived as "a threat" by the state because their activities are in perfect compatibility with Turkey's foreign policy objectives. For the first time, two major preconditions defined by the state in its relations with businessmen, "legitimacy" and "contribution to national interest" have been met by Kurdish businessmen. This new situation has enlarged their sphere of action so that they are more often invited to political meetings regarding the eventual resolution of the Kurdish question. As their activities match the national interest as defined by the state and its soft power strategies, they obtain legitimacy and access to the political sphere. Most Kurdish businessmen economically active in KRG are also members or representatives of business associations, while their activities in KRG reinforce their civil society affiliations and widen their field of action in negotiations with the Turkish state.

This situation of Kurdish businessmen can be compared to that of Turkish Jewish businessmen who enlarged their negotiation capacities with the state as a minority 
through their service in the state's foreign policy objectives, especially in the USA. As R. Kastoryano notes, an international political function was attributed to Jewish businessmen because of their involvement in transnational solidarity networks (Kastoryano 1992). Using this particular tool especially at the end of the Cold war, they created a pressure group supporting Turkish foreign policy strategies. Alongside their informal affiliation to Turkey's foreign policy objectives, they simultaneously formed a lobby to negotiate over its community interests.

Legitimate action recognised by the state internationally has thus been transformed into a national level benefit for minority members. As many interviewed Kurdish businessmen reported, these economic activities contribute to southeast Turkey's economic development. They are allowed by the state thanks to their contribution to foreign policy strategies. Thus Kurdish businessmen have a relative opportunity of access to the political sphere. This situation, actually, could provide the foundations for a Kurdish bourgeoisie. Soft power is strengthened by the participation of economic actors in creating the conditions for a non-state actor group's political participation. Turkey's economic soft power has had three main consequences for Kurdish businessmen, especially those based in southeast Turkey: first, taboos related to the existence of a Kurdish state have withered away, making the Kurdish question more freely discussed; second, economic integration has formed the basis of Turkey-KRG relations and reinforced as well as legitimised Kurdish businessmen's status with state authorities; finally, this economic exchange has enriched investors in southeast Turkey, who could constitute a source for the emergence of a Kurdish bourgeoisie.

\section{Conclusion}

By developing trade worth 11 billion dollars per year between Turkey and Iraq according to Turkish Ministry of Economy statistics for 2013 - Turkey's businessmen have contributed to the economic consolidation of Turkish soft power in the Middle East. As a concept related to power in general, soft power has usually been considered within a state-centric approach. However, soft power strategies require action by nonstate actors, such as businessmen, civil society organisations, artists or filmmakers, it is thanks to the contribution of non-state actors that soft power circulates.

The case of Turkey-KRG relations confirms this role of non-state actors. Business activities have been the basis of Turkish-Kurdish relations and contributed to the abandonment of several taboos related to the existence of a Kurdish state in the Middle East. As well as contributing to the Turkish state's soft power strategies in the Middle East, businessmen are also at the origin of a quite new phenomenon. Thanks to the compatibility of their activities with Turkey's recent foreign policy strategies, Turkey's Kurdish businessmen have obtained a new status with state actors. Their activities have been "legitimised", and they are now able to strengthen their negotiation capacities concerning their political and social demands concerning Turkey's Kurdish question. Thus, a particular group of non-state actors have benefitted from the consequences of the state's soft power strategies in order to reintroduce the minority question into domestic debate. The state's soft power strategy has thus become a tool for this particular group in domestic politics.

The economic activities of Turkey's businessmen in KRG have created a field for implementing Turkish soft power, paradoxically, despite - and sometimes against - the 
will and control of the state. By using their capacity for transnational action, these activities are challenging the state. This underlines the complex relation between private actors and the state in foreign policy, and weakens soft power as an analytical concept. This concept, which prioritises the intentions and actions of public actors, underestimates the complexity of relations between public and private actors, especially the transnational capacities and actions of private actors, as well as their ability to challenge the state and to escape from its control - as demonstrated in the particular case examined in this article. A further question appears about behaviours of these private actors towards the state and vice versa when domestic circumstances change dramatically around the Kurdish question in Turkey. A future fieldwork which will be based on interviews with the same businessmen in the South East can allow to compare the evolution of these business actors' relations with the state during the official peace process (2013-2015) and in the period of armed conflict between Turkish security forces and PKK (since summer 2015) and to bring explanations to the following question: What role can these local business actors play in the post conflict recovery and reconstruction period in the South East Turkey?

\section{BIBLIOGRAPHY}

Altunışık, Meliha Benli (2005). “The Turkish Model and Democratisation in the Middle East," Arab Studies Quarterly 27(1/2), pp. 45-63. URL: http://www.jstor.org/stable/41859009.

Atl1, Altay (2011). "Businessmen as Diplomats: The Role of Business Associations in Turkey's Foreign Economic Policy,” Insight Turkey 13(1), pp. 109-128. URL: http://file.insightturkey.com/ Files/Pdf/insight-turkey_vol_13_no_1_2011_atli.pdf.

Aron, Raymond (2008). Paix et guerre entre les nations, Paris, Calmann-Lévy

Aybar, C. Bülent; Mergen, A. Erhan; Perotti, Victor; McHardy Reid, David (2007). “Analysis of Attitudes of Turkish Citizens towards the Effects of European Union Membership on the Economic, Political and Cultural Environment," Turkish Studies 8(3), pp. 329-348. DOI: $10.1080 / 14683840701489084$.

Badie, Bertrand; Smouts, Marie-Claude (1995). Le Retournement du monde : Sociologie de la scène internationale, Paris, Presse des Sciences Politiques \& Dalloz.

Boratav, Korkut (2012). Türkiye İktisat Tarihi 1908-2009, Istanbul, Imge Kitabevi Yayıncılık.

Bourdieu, Pierre (1993). « Esprits d'État, Genèse et structure du champ bureaucratique ", Actes de la recherche en sciences sociales 96-97, pp. 49-62. DOI: 10.3406/arss.1993.3040.

Buğra, Ayșe (1987). “The Late Coming Tycoons of Turkey,” Journal of Economics and Administrative Studies 1(1), pp. ???.

Buğra, Ayșe (1998). “Class, Culture and State: An Analysis of Interest Representation by Two Turkish Business Associations," International Journal of Middle East Studies 30(4), pp. 521-539. URL: http://www.ata.boun.edu.tr/faculty/Ayse\%20Bugra/makaleler/Bugra,\%20Ayse_Class, \%20Culture\%20and\%20State.pdf. 
Buğra, Ayșe (2007). Devlet ve İșadamları, Istanbul, İletișim Yayınları

Carron de la Carrière, Guy (2002). « Omniprésente économie », in Frédéric Charillon (dir.), Politique étrangère Nouveaux regards, Paris, Presses de Sciences-Po, pp. ???.

Çandar, Cengiz (May 25, 2012), “Ișin içine 'Kürdistan petrolü’ girerse...," Hürriyet. URL: http:// www.hurriyet.com.tr/isin-icine-kurdistan-petrolu-girerse-20630287.

Chulov, Martin (January 22, 2016). "Iraqi Kurdistan President: time has come to redraw Middle East boundaries," The Guardian. URL: http://www.theguardian.com/world/2016/jan/22/kurdishindependence-closer-than-ever-says-massoud-barzani.

Çubukçu, Mete (November 3, 2009). "Barzani Ankara'ya Davet Bekliyor”, T24. URL: http:// t24.com.tr/yazarlar/mete-cubukcu/barzani-ankaraya-davet-bekliyor,1125.

Dodge, Toby, "Iraq: The contradictions of exogenous State-Building in historical perspective," Third World Quarterly, Vol. 27, No.1, 2006, pp. 187-200. DOI: 10.1080/01436590500370061.

Doyle, Michael (1997). Ways of War and Peace: Realism, Liberalism and Socialism, New York, Norton.

Haberler (May 16, 2008). “Diyarbakır Erbil Duhok Arasında Ekonomik İşbirliği,” Haberler. URL: http://www.haberler.com/diyarbakir-erbil-duhok-arasinda-ekonomik-isbirligi-haberi/.

Heper, Metin (1991). Strong State and Economic Interest Groups, The post-1980 Turkish Experience, Berlin, Walter de Gruyter.

Insel, Ahmet (2008). « La Turquie : un dynamisme économique mais des incertitudes politiques », in Christophe Jaffrelot, L'Enjeu mondial, Les pays émergents, Paris, Presses de Sciences-Po, 2008, pp. 129-136. URL: https://www.cairn.info/l-enjeu-mondial-1--9782724610871-page-129.htm.

Kalın, İbrahim (2012). “Soft Power and Public Diplomacy in Turkey,” Perceptions XVI (3), pp. 5-23. URL: http://sam.gov.tr/soft-power-and-public-diplomacy-in-turkey/.

Kastoryano, Riva (1992). « L'intégration politique par l'extérieur. La communauté juive de Turquie », Revue française de science politique 42(5), pp. 786-801. DOI: 10.3406/rfsp.1992.404342.

Keyder, çaǧlar (1987). State and Class in Turkey: A Study in Capitalist Development, London, New York, Verso.

Kirişçi, Kemal (2009). "The Transformation of Turkish Foreign Policy: The Rise of the Trading State," New Perspectives on Turkey 40, pp. 29-57. DOI: 10.1017/S0896634600005203.

Konda (2011). Biz Kimiz'10, Kürt Meselesi'nde Algı ve Beklentiler Araștırması, Bulgular Raporu, KONDA Araștırma ve Danıșmanlık. URL: http://akgul.bilkent.edu.tr/Konda/ 2011_06_KONDA_Kurt_Meselesinde_Algi_ve_Beklentiler.pdf.

Kutlay, Mustafa (2011). “Economy as the 'Practical Hand' of 'New Turkish Foreign Policy': A Political Economy Explanation,” Insight Turkey, 13(1), pp. 67-88. URL: http://ssrn.com/ abstract $=1972237$.

Nye, Joseph S. (1990). “Soft Power”, Foreign Policy 80, pp. 153-171. URL: http:// faculty.maxwell.syr.edu/rdenever/PPA-730-27/Nye\%201990.pdf.

Nye, Joseph S.; Keohane, Robert O. (eds.) (1972). Transnational Relations and World Politics, Cambridge, Harvard University Press.

Özdemirkıran, Merve (June 2013). Construire un État, briser des tabous. Les hommes d'affaires de Turquie entre la construction étatique du Gouvernement Régional du Kurdistan et la politique étrangère de la Turquie, PhD thesis, Institut d'Études Politiques de Paris. 
Öniș, Ziya; Bakır, Caner (2005). “Turkey’s Political Economy in the Age of Financial Globalisation: The Significance of the EU Anchor Contribution," Contribution presented at the conference Europeanisation and Transformation: Turkey in the Post-Helsinki Era, Koç University, Istanbul, December $2^{\text {nd }}-3^{\text {rd }}, 2005$. DOI: 10.1080/13608740701306086.

Öniș, Ziya (2006). “Turkey's Encounters with the New Europe : Multiple Transformations, Inherent Dilemmas and the Challenges ahead," Journal of Southern Europe and the Balkans 8(3), pp. 279-298. DOI: 10.1080/14613190601004814.

Pierson, Christopher, The Modern State, London, New York, Routledge, 1996.

Rosecrance, Richard (1986). The Rise of Trading State, New York, Basic Books.

Rosecrance, Richard (2010). “Bigger Is Better”, Foreign Affairs 89(3), pp. 42-50. URL: https:// www.foreignaffairs.com/articles/2010-05-01/bigger-better.

Vuving, A.L. (2009). "How Soft Power Works," Paper presented at the panel "Soft Power and Smart Power", American Political Science Association Annual Meeting, Toronto, 3 September 2009. URL: http://apcss.org/Publications/

Vuving\%20How\%20soft\%20power\%20works\%20APSA\%202009.pdf.

Winters, Jeffrey A. (1996). Power in Motion, New York, Cornell University Press.

Yankaya, Dilek (2013). La nouvelle bourgeoisie islamique Le modèle turc, Paris, PUF.

Zaman (October 31, 2009). “Kuzey Irak'la bir ilk: Davutoğlu Erbil'de Barzani ile görüștü,” Zaman. URL: http://www.zaman.com.tr/dunya_kirakla-bir-ilk-davutoglu-erbilde-barzani-ilegorustu_909915.html.

\section{NOTES}

1. "We the people of Iraq who have just risen from our stumble, and who are looking with confidence to the future through a republican, federal, democratic, pluralistic system, have resolved with the determination of our men, women, the elderly and youth, to respect the rules of law." The Iraqi state building process was legally started by this political will proclaimed in the preamble of the 2005 Iraqi constitution. The people of Iraq, which include several ethnic and religious groups, agreed on federal principles. This "exogenous state building" process (see Dodge 2006), led essentially by external actors (especially United States), has faced many difficulties from security to unemployment. The failure of the process worsened sectarian tensions between Shias and Sunnis and reinforced civil war conditions. Yet, in Northern Iraq, the Kurdish government, politically isolated from the rest of Iraq since 1991, undertook a relatively successful state building process. Although this can not be considered separately from the central government in Bagdad, the Kurdish Regional Government (KRG) is working in many domains as an autonomous political entity that can be called "a quasi state" (see Özdemirkıran, 2013). Dispersed across four countries (Turkey, Iraq, Iran and Syria), Kurdish people have never had an independent nation state. Thus, the political transformation in Iraq that started after the US intervention in 1991 gave Iraqi Kurds an opportunity to "govern themselves". However, they experienced a period of internal fighting in which the territory of Kurdistan in Iraq was divided between the two warring sides of KDP and PUK. The isolated status of Northern Iraq also prevented Kurds from building a state as they lived under a double embargo (international sanctions on the Saddam regime through the oil for food program and economic restrictions imposed by Saddam Hussein against the Kurdish region). In 2005, for the first time in their history, Kurdish people gained federal status and control of economic resources when the Iraqi state was restructured with the constitution of 2005. Today, 
the KRG has a monopoly of violence in Northern Iraq in Weberian terms, has economic independence from Bagdad as it can control $17 \%$ of Iraqi oil, has its own police force and army [peshmerga], uses its own flag and collects taxes. Thus, it is effectively operating as a state (see Pierson 1996). KRG is not completely independent in its foreign policy but has a lot more privileges than many other federal states. For example, KRG controls the Turkey-Iraq and IranIraq borders so foreigners crossing either border receive a KRG stamp on their passports and has to apply for an Iraqi visa to travel on to the rest of Iraq. KRG has also diplomatic representation abroad and conducts negotiations in its foreign relations, for example with Turkey regarding energy and border security, despite the opposition of central government. In short, although KRG is not officially an independent state, it can clearly categorised as a quasi-state.

2. Interview with Deniz Kutlu, Commercial attaché of Turkish consulate in Erbil, Erbil, January 9, 2011.

3. The data was collected for my PhD thesis. (Özdemirkıran 2013).

4. See Richard Rosecrance's 2010 article in Foreign Affairs, in which he revisits his idea of a "trading world" to criticise these aspects, above all its imperfections and dysfunctional nature, notably regarding "small" trading states in Southeast Asia.

5. Ayșe Buğra concludes that Turkish businessmen do not behave according to the classical rationality of the market economy and feel a lack of confidence regarding the "legitimacy" of their activities, specifically for obtaining purely material benefits. See also Ayşe Buğra (1987).

6. For a detailed analysis of the rise of business association as an actor in Foreign Policy (organisations such as DEIK, TUSKON) see Altay Atlı's (2011).

7. MÜSİAD is the acronym for Müstakil Sanayiciler ve İșadamları Derneǧi, founded in 1999. This association is composed of entrepreneurs that define themselves as "pious" and conservative, generally originally from cities in Anatolia. The "MÜ" in MÜSİAD means müstakil (independent), yet lets itself also be known as müslüman (Muslim in Turkish) and refers to this newly emerging class of the bourgeoisie. For a detailed analysis of this association, see Yankaya (2013).

8. For a comparative analysis of the two associations published before the rise to power of the AKP, see Buğra (1998).

9. The Turkish Confederation of Businessmen and Industrialists (TUSKON) also must be cited her as another leading organisation who contributed to state's FP strategies abroad, especially in Asia and Africa. Blamed by the government for its alleged ties with the Gülen movement (in conflict with the government since 2013 - see other articles on this movement in this special issue), this organisation does not have an active role anymore in Turkey's economic diplomacy.

10. For example, Prime Minister Erdoğan declared during his visit to Iraq in 2008 that trade capacity between Turkey and Iraq should reach 25 billion dollars. A strategic cooperation agreement was signed during this visit, with both Iraqi and Turkish leaders underlining the importance of KRG's participation to economic integration between Turkey and Iraq.

11. Interview with İlnur Cevik, Ankara, May 26, 2008.

12. Only interviews directly linked to the topic of this special issue are mentioned in this article. For detailed information about the sociological characteristics of the businessmen, see Özdemirkıran (2013).

13. This situation of mutual hostility has increased since KRG President Massoud Barzani was welcomed by Prime Minister Erdoğan in 2013 in Diyarbakır, the symbolic capital city for Turkey's Kurds, and since the "peace process" on Kurdish question started in Turkey.

14. The International Bagdad Expo was transferred to Gaziantep for security reasons. The fair was organised as the Expo Gateway to Iraq from 2006 to 2010.

15. Interview with Mehmet Arslan, President of Gaziantep Chamber of Commerce, Gaziantep, June 23, 2008.

16. This protocol for the development of economic cooperation was signed between Diyarbakır Chamber of Commerce and Industry, Erbil Chamber of Commerce and Duhok Chamber of 
Commerce in May 2008. For the content and Mehmet Kaya's (former President of Diyarbakır Chamber of Commerce and Industry) and Dara Ali's (former President of Erbil Chamber of Commerce) declarations see (Haberler May 16, 2008).

17. Interview with Galip Ensarioğlu, President of Diyarbakır Chamber of Commerce and Industry, Diyarbakır, May 13, 2009 (G. Ensarioğlu is currently a deputy of AKP).

18. Interview with Sıdıka Halıcıoğlu, President of Iraqi Turkish Businessmen and Businesswomen Association et Erkut Temiz, Vice-president of Iraqi Turkish Businessmen and Businesswomen Association, Istanbul, June 4, 2010.

19. Interview with Soran Aziz, Vice-president of Erbil Chamber of Commerce, Erbil, January 9 , 2011.

20. Interview with Haktan Akın, Istanbul, May 31, 2010.

21. Interview with Soran Aziz, Vice-president of Erbil Chamber of Commerce, Erbil, January 9 , 2011.

22. During its third term in office, beginning in 2011, the AKP government modified the structure of ministers with the activities of the Under-Secretary for Foreign Trade being re-structured in accordance with the Ministry of the Economy, which was conceived as a new ministry. This decision indicates the importance that AKP leaders accord to international trade in Turkey's economy as they see foreign trade (exports) as the spine of the Turkish economy.

23. Interview with Sıdıka Halıcıoğlu, Istanbul, June 4, 2010.

24. Interview with Soran Aziz, Erbil, January 9, 2011.

25. Ibid.

26. Interview with Deniz Kutlu, Commercial attaché of Turkish consulate in Erbil, September 1, 2011.

27. Interview with Muhammed S., Erbil, January 10, 2011.

28. Official negotiations between Turkish state authorities (government, intelligence services, etc.) and Abdullah Öcalan, founder of PKK, in jail on İmralı Island are at the origin of the peace process (known also solution process).

29. According to a 2010 survey carried out by KONDA with 10,393 respondents, over $40 \%$ of Turks do not want to share their private sphere with a Kurd (as a neighbour, partner or relative). Even if Turks and Kurds affirm their willingness for a democratic resolution, $32.4 \%$ of Turks still think that only coercive methods can resolve the Kurdish question. See (Konda 2011).

30. Thanks to the visits of Turkish President Abdullah Gül in 2009 and Minister of Foreign affairs Ahmet Davutoğlu in 2011, and finally thanks to the opening of the Turkish consulate in Erbil, bilateral political relations have been normalised.

31. Interview with Mehmet Kaya, Diyarbakır, June 2, 2010.

32. Interview with Ferda Cemiloğlu, Erbil, January 9, 2011.

\section{ABSTRACTS}

When the new Iraqi constitution was proclaimed in 2005, Kurds obtained the opportunity to build a de facto state in the north of Iraq. As a neighbour state Turkey has involved in the infrastructure construction of Kurdish Regional Government (KRG) through the activities of businessmen although the formation of a Kurdish state in the Middle East was a taboo in 
Ankara's foreign policy. These business activities allowed to Turkey and KRG to build bilateral political relations as well as to strengthen Turkey's soft power in the region. At the same time, as their activities were considered compatible with the state's foreign policy strategies Kurdish businessmen of Turkey benefited from these activities to reintroduce a minority question into the domestic political debate. This article shows how by using their capacity for transnational action, a group of non-state actors contributes to state's soft power and challenges at the same time the state in order to strengthen its influence in domestic politics. Through the case of Turkey's businessmen in KRG, this article analyzes how the concept of soft power gains a larger definition as a means for private actors.

INDEX

Keywords: Kurdish Regional Government, KRG-Turkey relations, non-state actors, soft power

\section{AUTHOR}

\section{MERVE ÖZDEMIRKIRAN}

Assistant professor Marmara University, Istanbul mozdemirkiran@gmail.com 